\author{
A. Alkozhayeva (iD , A.T. Zhussanbayeva \\ Al-Farabi Kazakh National University, Kazakhstan, Almaty, \\ e-mail: alkozhaas20@gmail.com, \\ e-mail: zhusanbaeva70@gmail.com
}

\title{
SEMANTIC ADAPTATION AND EVOLUTION OF KAZAKH LEXICAL ELEMENTS IDENTIFIED IN THE RUSSIAN-LANGUAGE NEWSPAPERS OF KAZAKHSTAN IN THE SECOND HALF OF THE XIX AND AT THE END OF THE XX CENTURIES
}

The article presents a historical review of newspapers in which Kazakh lexical elements were widely used and performed an educational function. The purpose of the research is to identify the mechanism of borrowing, development and exploitation of Kazakhisms in Russian-language newspapers in the late XIX and late XX centuries. When conducting this linguistic analysis, traditional linguistic methods were used.

The results of the study of a comparative analysis of Kazakhisms of two historical periods allowed us to identify such trends in the development of the borrowing process as the transition from borrowing lexical units with a specific objective value to borrowing units of a cultural character; reduction of time of development of kazakhisms; a change in the function of Kazakhs in a newspaper text; change of the ways of borrowing. These data clarify, supplement and concretize a number of provisions of the general theory of borrowing, the theory of language contacts.

In conclusion, based on the study, conclusions are formulated: - the development of Kazakh vocabulary, entered through oral speech, began with a written fixation reflecting their pronunciation; - during the development of Kazakhisms in the second half of the XIX century. The Russian lexical-semantic system retained their semantic volume, however, it made adjustments to the connotation of meanings; The conducted scientific research shows the presence of large changes both in the mechanism of borrowing by the Russian language of Kazakhisms and in the body of borrowings, their functions, which is a reflection of changes in psychology, national identity, objective conditions for the functioning of languages.

Key words: connotation, semantics, Kazakhisms, newspapers, vocabulary, language contacts.

$$
\begin{gathered}
\text { А.С. Алкожаева, А.Т. Жусанбаева } \\
\text { Әл-Фараби атындағы Қазақ, ұлттық университетінің аға оқытушысы, Қазақстан, Алматы қ., } \\
\text { e-mail: alkozhaas20@gmail.com, } \\
\text { e-mail: zhusanbaeva70@gmail.com. }
\end{gathered}
$$

XIX ғасырдың екінші жартысында және XX ғасырдың аяғында

Қазақстанның орыс тілді газеттерінде анықталған қазақ мексикалық элементтердің семантикалық бейімдекуі және эволюциясы

Мақалада XIX ғасырдың соңы мен XX ғасырдың аяғындағы орыс тілді газеттерде қазақ тілінен енген сөздер сарапталады. МақалаАа сол кезеңлегі газет бетінде жарық көрген қазақ тілінен енген сөздер кеңінен қолданылған материалдарға талдау жасалған. Тіл фактілерін қарастыру кезінде қазіргі лингвистикалық зерттеулер арнасында, яғни салғастырма, функционалды лингвистика және мингвомәдениеттаным ілімдері талаптарына сай орындалды.

Зерттеудің мақсаты - XIX ғасырдың аяғы мен XX ғасырдың аяғындағы орыс тілді газеттердегі қазақ тілінен енген сөздердің пайда болуы, даму және жұмыс істеу механизмін анықтау.

Зерттеу жұмысының өзектілігі бірнеше факторлармен айқындалады: Біріншіден, XIX ғасырдың екінші жартысындағы орыс тілді газеттерде кездесетін қазақ тілінен кірген сөздер мен қазіргі орысша газеттердегі қазақ лексикасын салғастыру, олардың орыс және қазақ тілі сөздіктеріндегі мағыналарын түсіндіру қазақ сөздерінің мағыналық жағынан даму бағыты мен қарқынын байқауға, сондай-ақ жаңа лексемалардың пайда болуы, көне сөздердің жаңа мағынаға ие болуы, жаңа сөз тудыру модельдері мен функционалдық-стилистикалық өзгерістердің орын алуын аңдауға мүмкіндік береді.

Нәтижеде екі тарихи кезеңдегі қазақ тілінен енген сөздерді салыстырмалы та^дау нәтижелері өзара әрекеттесу процесінің белгілі бір объективті мәні бар лексикалық бірліктерден мәдени сипаттағы өзара әрекеттесу бірегейлігіне көшу сияқты даму үрдісін анықтауға мүмкіндік 
берді; қазақ тілінен енген сөздердің дамуында уақыттың азаюы; қазақ тілді сөздердің газет мәтіндеріндегі қызметінің өзгерісі; өзара әрекеттесу тәсілдерінің өзгеруі.

Қорытындылай келе, зерттеу негізінде келесі тұжырымлар жасалады: - ауызекі сөйлеу тілі арқылы пайда болған қазақ мексикасының дамуы олардың айтылуын көрсететін жазбаша бекітуден басталды. Орыс мексика-семантикалық жүйесі олардың семантикалық көлемін сақтап қа^ды, дегенмен мағыналардың семантикалық бейімделуіне түзетулер енгізді; қазіргі газеттердің тілі терең семантикалық және стилистикалық өзгерістерге ұшырайды, жүргізілген ғылыми зерттеулер психологиядағы, ұлттық ерекшелігіндегі, тілдердің өмір сүруінің объективті жағдайындағы көріністердің бірі болып табылатын қазақшылдықтың орыс тілін игеру механизмінде де, өзара әрекеттесу құрылымында да, олардың қызметтерінде де үлкен өзгерістердің болуын көрсетеді.

Түйін сөздер: коннотация, семантика, қазақ, газет, сөздік, тілдік байланыс.

\author{
А.С. Алкожаева, А.Т. Жусанбаева \\ Казахский национальный университет им. аль-Фараби, Казахстан, г. Алматы, \\ e-mail: alkozhaas20@gmail.com, \\ e-mail: zhusanbaeva70@gmail.com.
}

\title{
Семантическая адаптация и эволюция казахских лексических элементов в русскоязычных газетах Казахстана второй половины XIX и конца XX веков
}

В статье анализируются казахские лексические элементы на материале русскоязычных газет второй половины XIX и конца XX века. В статье преАставлен исторический обзор газет, в которых казахские лексические элементы широко использовались и выполняли просветительскую функцию.

Цель исследования - выявление механизма заимствования, освоения и функционирования казахизмов в русскоязычных газетах половины XIX и конца XX вв. Основным принципом исследования в статье является последовательное сочетание социального и кингвистического подходов при рассмотрении фактов языка. При проведении Аанного ^ингвистического анализа применямись традиционные мингвистические методы.

В работе использован комплекс методов: синхронно-описательный, предполагающий отбор, описание, сопоставление лексических еАиниц в определенный период языкового развития; Аиахронический метоА, выявляющий особенности семантики и функций языковых единиц на разных этапах развития языка; сопоставительно-функциональный, применяемый А^я сопоставления особенностей функционирования слов в казахском и русском языках; мингвостилистический, при котором исследуются языковые еАиницы с точки зрения их функционального предназначения, а также приемы контекстуального, компонентного анализа и количественная характеристика изучаемых языковых единиц.

Результаты исследования сравнительного анализа казахизмов двух исторических периодов позволили выявить такие тенденции в развитии процесса заимствования, как переход от заимствования мексических еАиниц с конкретно-предметным значением к заимствованию единиц культурологического характера; сокращение времени освоения казахизмов; изменение функции казахизмов в газетном тексте; изменение путей заимствования. Эти Аанные уточняют, Аополняют и конкретизируют ряд положений общей теории заимствования, теории языковых контактов. В заключении на основе проведенного исследования сформулированы выводы: освоение казахской мексики, вошедшей через устную речь, начиналось с письменной фиксации, отражающей их произношение; при освоении казахизмов во II половине XIX в. русская лексикосемантическая система сохраняла их смысловой объем, однако вносила коррективы в коннотацию значений; язык современных газет претерпевает глубокие семантические и стилистические изменения, которые через лексику отражают перемены в политической жизни, так и в корпусе заимствований, их функциях, что является отражением перемен в психологии, национальном самосознании, объективных условий функционирования языков.

Кмючевые слова: коннотация, семантика, казахизмы, газеты, мексика, языковые контакты.

\section{Condition of the problem}

Studying of the language relations in the multinational state was always an actual problem. At the present stage when languages of the people of the CIS develop as a form and a tool of national spiritual cultures, when Russian language in the territory of Kazakhstan acts as language of international communication (the constitution of RK, Art. 8), the problem of research of the Russian and Kazakh languages gains special relevance. There were cardinal changes in social, economic, 
political life of Kazakhstan during the periods investigated in article (in the II half of the XIXth and at the end of the XXth centuries): completion of imperial colonization of the territory of Central Asia and Kazakhstan, establishment of new Russian administration, destruction of a socialist formation, gain of the sovereignty by the Republic, formation of new democratic society at the end of the XXth century.

All these external-linguistic factors had a considerable impact on culture, consciousness and language. There is a change of cultural, axiological paradigms and communicative behavior of native speakers in lingua-cultural community of Kazakhstan.

Links of the Russian and Turkic people originate in depth of history. It has been long since the trade and diplomatic relations between nations were developed, which were accompanied by language contacts as a result of historically developed conditions.

The facts of history give the chance to claim that the Russian-Kazakh language contacts were emerged long before the beginning of the accession of Kazakhs into Russia. The second half of the XIXth century is the special period in the RussianKazakh relations. The territory of present Kazakhstan completely turned into submission of imperial Russia. Management, development of the territory of Kazakhstan was equivalent of finding of a huge wealth for the imperial Russia. "The plan for management of the colonial people was brought to perfection. First of all, it was planned to study life, customs, traditions, language, culture, history and ethnography, oral creativity, geography, subjects of material culture and a field of activity in order to keep the people in obedience to the Russian colonialists. Therefore, for these purpose officials, orientalists, missionaries, merchants, travelers and the entire expeditionary forces were sent to all corners of Kazakhstan (Lenger F., 1995).

Penetration of the capitalist relations into the steppe accelerated process of decomposition of a nomadic way of life of the population and patriarchal-feudal relations in the Kazakh villages, gave birth of new industries, promoted public division of labor and formation of democratic culture of the Kazakh people.

Accession of Kazakhstan into Russia had a progressive value: the Russian-Kazakh schools, mail, telegraph were opened, the railroads were built, books were published, and periodicals were appeared.

The first newspaper was issued in the Kazakh and Uzbek languages as an appendix to «Turkestan bulletin» in 1870 in Tashkent according to the petition of the Turkestan governor general Kauffman.

The edition of «Bullletin» of the government has pursued quite definite purposes. Printing word was necessary first of all to strengthen the power and authority of the Turkestan governor general, for glorification of tsarism, to carry out its policy.

The regulations and orders of the Turkestan governor-general of areas, addressed to local indigenous people, decisions of judicial authorities, trade information, news from Russia and other states, news on economic life are placed on pages of newspapers «Turkistan Bulletin» and its «Appendix» («Turkestan ualayatinin gazeti») according to the program approved by the government .

Over time newspapers are beyond the scope of this program and begin the publication of the materials relating to areas of culture, history and literature of local population. On pages of newspapers appeared medical and veterinary advice useful for people, articles of popular scientific character about phenomena of nature, about news of science and technology, about the cultural centers in the province.

The second official newspaper issued in the Kazakh and Russian languages was «Dala ualayatinin gazeti» (in Russian language «Kyrgyz steppe newspaper»).

«Kyrgyz steppe newspaper» started being issued in Omsk at office of the Steppe governor-general since January 1, 1888 and existed from Mart, 1902 till 1894. «Dala ualayatinin gazeti» was issued as «a special addition to Akmola regional bulletin», and since 1894 in the form of the appendix to «Bulletin» of Akmola, Semipalatinsk and Semirechenskii areas and published weekly in the Kazakh and Russian languages.

Great importance in the interaction and mutual influence of the Russian and Kazakh languages had such newspapers as «Turgayskaya gazeta» (Turgay newspaper) and «Semirechesnkie oblastnye vedomosti» (Semirechenskii regional bulletin).

All these historical events have played an important role in bringing together the Russian-Kazakh peoples, therefore, in contacting both language systems that found reflection in the lexis of both Russian and Kazakh languages.

The statement of the course and results of our study needs to be preceded by some remarks concerning scientific-conceptual framework, in particular, the basic terms and conditions of the theory of loans.

Foreign-language lexis is a general name of the words of a foreign-language origin mastered and undeveloped by the receiving language. 
The borrowed lexis is a foreign language lexis, acquired by the recipient language.

Kazakhism is a lexical unit borrowed by Russian from Kazakh or through the Kazakh language.

«Turkisms are units of all levels of language borrowed by Russian (from Turkic or through their means) in order to meet the needs arising in the receiving language» (Sagdullayev D.S., 1975).

Studying of Turkic lexical elements in the Russian language has the old history which is going back to the first half of the XVIIIth century. The first attempts of the analysis of Turkisms in the Russian language are presented in works of H.D. Fren, Ya. O. Yartsov, F.I. Erdman who made «lists» of words of east origin, analyzed the structure of Turkism's in the Russian lexis and tried to track historical circumstances of loanwords. In the second half of the XVIIIth century and at the beginning of the XIXth century the scientific studies which had practical character were intensified among which it is necessary to note the following works of I.I. Sreznevskii, A.O. Mukhlinskii, I.N. Berezin, A.A. Borzenko, V.V. Grigoriev, L. Budagov, V.V. Radlov. Researchers subjected a wide and detailed analysis of Turkism in the Russian, Polish, Greek, Albanian, Bulgarian, Serbian languages.

Accumulated factual material was used by researchers of the XIX-XXth centuries, such as F.E.Korsh, P.M.Melioranskii, A.V.Mirtov, Kh.Kh. Makhmudov, E.V. Sevortyan, I.V. Dobrodomov, A.E.Suprun, I.I. Nazarov, N.I. Gaynullina and etc. The special place in the Russian-Turkological works was taken by textual researches of A.N. Kononov, S.E. Malova who used cultural and historical data in the study of different texts.

Now the multidimensionality of approaches to consideration of Turkism is noted in scientific literature. Researchers analyze Turkism on the material of the ancient Russian monuments (I.G. Dobrodomov 1996, Kh.Kh. Makhmudov 1943), in dialectical lexis (L.L. Ayupova 1975, A. A. Selimov 1966), in the aspect of diachrony (Yu.S.Sorokin, N. I. Gaynullina, V.M. Aristova), on certain historical eras (A.K. Aslanov, V.D. Arakin), in word-formation system of the Russian language (L.Zh. Umurzakova 1982), on theme groups (A.K. Zharimbetov, D.S.Setarov), in language of artistic and periodical prints (K. G. Menges 1979, R.T.Mendekinova 1982, Yu. I. Chernysheva 1971, A. M. Tanabayeva 1982, N. A. Tikhonova 1970, P.M.Chumbalova 1975, K. M. Nyshanbayev 1990). The Kazakh researchers made a significant contribution to the development of issues on semantic changes, semantic shifts, stylistic functions of loans in language of fictional works
(R.S.Zuyeva, L. K. Zhanalina, Z.K.Akhmetzhanova, M. M. Kopylenko, Z.K.Sabitova, N. Ongarbayeva).

This article highlights the part of scientific research - the monograph «Kazakhisms in the Russian-language newspapers of Kazakhstan (in the second half of XIXth and at the end of the XXth centuries)».

Methodology and material of the research.

The Kazak lexis is served as a material for the study (2,5 thousand word usages). The source of selection of factual material were the following newspapers such as «Turkestanskie vedomosti» (Turkestan bulletin) (1870-1890); «Kirgizskaya stepnaya gazeta» (Kyrgyz steppe newspaper) (1888-1902); «Turgayskaya gazeta» (Turgay newspaper) (1892-1903); «Semirechenskie oblasnye vedomosti» (Semirechenskii regional bulletin) (1880 - 1890), «Kazakhstanskaya Pravda» (Kazakhstan's truth) (1995 - 2000); «Novoe pokolenie» (New generation) (1997-2001); « Ogni Alatau» (Fires of Alatau) (1995-2000); «Caravan» (1996-2001); «Megapolis» (1993-2000). Traditional linguistic methods and techniques (synchronously - descriptive, diachronic, contrastive-functional, lingua -stylistic, and as well as techniques of the contextual and component analysis) were used.

During the analysis the following dictionaries were used: «Slovar' tserkovno-slavyanskogo i russkogo yazyka»" (Dictionary of the Church -Slavonic and Russian language) (1847); Ilminskii N. I. « Materialy k izucheniyu kirgizskogo narechiya» (Materials to studying of the Kyrgyz adverb) (Kazan, 1861); Explanatory dictionary of the Kazakh language (1974-1980); Shipova E.N. «Slovar" tyurkizmov v russkom yazyke» (The dictionary of Turkism in the Russian language) Alma-Ata, 1976); Dal V. I. «Slovar' zhivogo velikorusskogo yazyka» (Dictionary of great Russian language) (19811982); etc.

\section{Results of the research}

The analysis of lexical-semantic groups of Kazakhisms, excerpted from «Kyrgyz steppe newspaper», «Turkestan bulletin», «Turgay newspaper», «Semirechenskii regional bulletin», gave the chance to track active functioning of Kazakhism designating national-specific realias of the Kazakh people: cultural-historical events, lifehousehold relations and subjects, features of climatic conditions and living environment of Kazakhs. For example, active entry of new concepts connected with cattle breeding into "Turgay newspaper» is explained by that the Russian trade capital got into 
the most remote regions of edge, closely connecting local cattle breeding economy with the markets of Russia, Central Asia. So, the extended coverage in «Kyrgyz steppe newspaper» problems of transition of Kazakh nomads to a settled way of life, justice issues, relationships of the Kazakh tribes, cultural life of society led to emergence of the Kazakhism designating a common law (aiyp, kun, talak, zhertamyrlyk, kondas), and also kazakhism-agents (zhatak, zharly, kedey, bi, atkaminer). Authors of «Turkestan bulletin» paid much attention to questions of religion, land use, irrigation therefore there is an active use of lexis relating to religion (imam, baksy, hadzh, namaz, zam-zam suy), to agriculture (ketmen, zhagara, biday, laucha, kyariz and etc.).

Observations have also shown that a certain part of Kazakhism is in high-frequent use with a wide range of their dispersion on all length of the text.

The Kazakh lexis which got into Russianlanguage newspapers joined in difficult figurative system and it also carried out expressional and stylistic function along with the logical-conceptual function.

Tropes and figures, revealing the logic of the national language thinking led to the development of model of the world in the minds of the Kazakh people, all of which determined the peculiarity of the language style of the Russian media in Kazakhstan in the second half of the XIXth century.

Let's consider words and phrases that act as an expressional-semantic center of metaphors and comparative-metaphorical structures. For example:

- The steep ridges, which ran away from the ridge of Uch-Kul, are like a herd of red argamaks (breed of fast horses) at the watering over rapids of Ak-Shirak «(TV. - 1879. -№18). The sun was gone; Kutan-tau's bulk was painted in the bluish-violet color. Young kuyanchik-month was lit in the sky (TV. -1883-№3). And suddenly Kasymbek felt that hidden melancholy was going away and behind him like a winter coat of nar (camel) (TV-1888-№18).

Highlighted expressions surprisingly accurately reproduce the national coloring; reflect the specifics of life peculiar to the Kazakh steppe. Sometimes there is a kind of «expansion» of an image based on a variety of associative links, the origins of which are rooted in the folk tradition.

- We also know that when Itbay was born, that «kok-ogyz» (a gray bull) was moved for the first time on which stands the land, and for the first time it was shaken then»(KSG. - 1890. - p.199). Anxiety was so strong that gusty terrible storm fire acted with jumps, jumped like a fiery "shaitan» (a devil or an unbelieving class of jinn in Islamic myth), suddenly flew forward and to the sides. (TV-1879-№18).

The use of word «kok-ogyz» (a gray bull) in a figurative sense is directed on strengthening the negative image of the characteristic of the villain person.

Kazakhisms were used in pre-revolutionary newspapers as means of the characteristic of the represented environment and an era, a tool of creating artistic images, means of expression of an author's assessment.

One of the decisive moments of adaptation of Kazahisms is its semantic development. While developing Kazahisms the Russian lexical-semantic system keeps their semantic volume, but made adjustments to the connotation of meanings.

The semantic analysis showed that the Kazakh words passed various ways of semantic transformations.

Some Kazakhisms kept their semantic structure, generally it is the monosemic words relating to everyday and household lexis: ayran (a kind of drink which is made from milk), dombra (a national instrument), zhaulyk (a big scarf and a kind of headdress of the married woman), tenge (a national currency), argamak (a breed of fast horse), murundyk (a small stick inserted through the nasal cartilage of a camel or a bull, which is tied to a leash) and etc. At development of the words which are characterized in the Kazakh language by polysemy, one or several meanings of words stand for the borrowed material, the semantic structure of Kazakhism becomes simpler, i.e. there is a semantics narrowing: bayga (a horse race), aiyp (fault, penalty, fine), bay (the rich), kap (a influx in the trunk, branches and roots of a tree), tamyr (aroot), zhigit (a male guy, boy) and etc. For example, in the Kazakh language the word aiyp has several meanings: 1 . fault of the person for any offense; 2 . a fine from the guilty person; 3 . shortcoming or defect.

Compare: The shortcoming of pheasant is its ugliness. (KTTS. P 115).

The word aiyp is used in the second meaning in newspapers:

- Each crime has the personal character and guilty has to pay fine (aiyp) to the victim as a repayment for the previously existing right of punishment (KSG. - 1901. - page 766). (KSG. 1901.P.766).

The word tamasha in the Kazakh language has three meanings: 1 . cheerful show; 2 . very good, special (adjective); 3. Sight.

- Compare.: Saule went around the city and observed its sights (KTTS. Page 576). 
- This word is used only in the first meaning in pre-revolutionary newspapers:

- According to the custom the people couldn't but marksuch event in an established way, having arranged three-day «toy» (celebration) or "tamasha» on which performed a native-acrobat (TV.-1896.-№54).

In the course of functioning many Kazakhisms were undergone different kind of changes in meaning and the development of new meanings in pre-revolutionary newspapers: atkaminer, baigush, aksakal; the development of additional meaning: tore, sultan, zhigit, baranta.

The word "aksakal» was used in the following meanings: 1 . the old man; 2 . the elder of the clan; 3. respected, influential person; 4. the respectful address to the senior on age (KTTS. Page 97).

All these meanings of the word «aksakal» are noted in the studied newspapers, but there are also other new meaning:

1. Aksakal - «the local police government»:

- None of rural police government (aksakals, elders, country rulers) didn't consider themselves to have the right to act in a direct obligation for a position differently, as through by a push of the order... (TV. -1879 . - No. 17).

2. The market aksakal - «the employee of administration of a market»:

- Mullah came with two other market aksakals and with the fourth, who was a witness and a owner of a teahouse. They approved the transaction at the presence of everybody. (KSG.-1900. - p. 239).

3. Aryk - aksakal - «irrigator»:

- The officials of management of agriculture and experienced irrigator who were not one year on fight against grasshopper were appointed to help them (TG. - 1906.-№17).

Kazakhism «atkaminer» before accession to imperial Russia meant «a horseman who carried out urgent instructions of bii, aksakals, the rich influential man» (KTTS.P.48).

In the language of pre-revolutionary newspapers the word atkaminer is used in new meaning: «judicial officer, official, representative of public administration».

The Kirgiz, arranging the feast, don't think about the poor at all, and try to please atkaminer in everything. At last if the organizers of the feast don't satisfy all of their whims, they will definitely try to make a scandal, to start a dispute or quarrel. (KSG1894-P.332).

Materials of the Russian-speaking media of Kazakhstan for the period between 1870-1911 and 1990-2000 visually indicate the orientation and tendencies of development, interaction and interference of two contacting languages - Russian and Kazakh.

Long economic, social- household contacts between Russians and Kazakhs, as well as developing of bilingualism at some part of the Russians living in the country, led to the fact that language of the modern Russian-speaking media of Kazakhstan hasn't dried up the demand for the need of the Kazakh loans.

The majority of words borrowed in the second half of XIXth century from the Kazakh language are historical exoticisms. The period of their entry into lexical-semantic system of language is preceded by a stage when the denoting objects are perceived by the stranger; each new lexeme passes a kind of language «quarantine» necessary for the movement through a step of an initial occasional use into the category of usual words.

Comparison of the corpus of loans from the Kazakh language recorded in the Russian-language newspapers in the II half of the XIXth century and Kazakhisms, which are used in the Russian press at the end of the XXth century revealed the following picture:

A certain part of Kazakhisms, used on pages of the Russian-language newspapers at the end of the XXth century, hasn't changed its semantic volume. For example, related lexemes that differ in being too much detailed than in the Russian language actively function in modern newspapers: nagashy (a relative from your mother's side), ene (a mother-in-law), zhenge (a wife of elder brother or a close relative), ata (a grandfather), apa (a grandmother), kelin (a bride), kaiyn (relatives of husband or wife).

The part of Kazakhisms lost its original meaning, getting a new semantic shade and a new connotation in modern newspapers: myrza (a kind of address to a man), sultan (a head of the country), hakim (a head of the region of a country), aga (an elder brother), tokal ( a younger wife), nuker (a soldier or a person from higher class), barymta (one form of the solution of the disputes: unauthorized capture, stealing cattle - herds of horses - from the offender as a compensation of the caused damage), aksakal (the old respected person), hanym (a kind of address to a woman), batyr (a hero), bay (a rich person), tumar (usually written spell on paper that is folded in a triangle shape and sewn in cloth and worn on a cord around child's neck), kalym (money paid for a new bribe) and etc.

For example, the lexeme sultan in the Russianlanguage newspapers was used earlier in the meaning of «aristocrat», «descendant of Genghis Khan, chingizid», «blue blood». In the second half 
of the XIXth century the lexeme sultan gains an additional meaning - «an administrative position»: In modern newspapers this lexeme is used in the meaning of «the governor in some countries of the East» and «the best among all guys».

Example: Sultans Kenisary and his son Sadyk are well-known figures in the Kyrgyz steppes and Turkestan region... The grandfather of the dead Arun, Kazangap, due to the choice of Kyrgyz from the Bayan-aul village, was approved by the authorities to the position of senior Sultan - for diligent service to the White tsar. Kazangap was promoted to the rank of Major (KSG.-1895. - P. 412).

Beauty contests such as "Almaty aruy» and "Zhigit Sultany» are annually held at many schools of the city (Caravan No. 5.1999).

The further destiny of the lexeme tokal isn't less interesting. The lexeme tokal in 10-volumed dictionary stands for «a younger wife» (KTTS). In the Kazakh language this lexeme has a connotation of «a wife who is deprived of the rights», "a wife who is on the second place after baybishe (the first wife)». Example: child who was born from tokal (i.e. indirect inheritant) (KTTS).

In the Russian-language newspapers in the II half of the XIXth century the word tokal is used only in denotative meaning without additional semantic shades: - Do you want? Well, so marry!... Pay the father kalym (a bride's wealth) and take me as tokal! (KSG.-1891. - P. 351).

In newspapers at the end of the XXth century the word tokal is used not only in usual seme of «a younger wife» (usually in materials about the past), but also starts gaining an additional meaning of «a lover» or «an unofficial wife»: "At the age of seventy uncle Rayymbek decided to begin all over again. He moved from the village to Almaty and got married to tokal, a wife who is about twenty years younger than him (Caravan.-1999. P. 248). In his spare time Azamat went to see his girlfriend Alena, whom he called as tokal for her eyes. (Ekspres K-1996 -№7) Some unmarried beauties at the age of forty begin to make strict requirements to their illegal «husbands», trying to get out of the humiliating status of being «tokal». (Caravan-1998.-№48).

In the language of modern newspapers it is possible to note activation of the use of many obsolete words which are now filled with the new contents.

The lexeme kumar occurred in pre-revolutionary newspapers in the meaning of «a passion to something gambling (a card play, bones).

Now the lexeme kumar got into the category of jargons and it became the synonym of words such as euphoria, to be drugged, to bliss out, in the meaning of «being smoked, drugged»:

- Every addicted person knows these words kumar, withdrawal pains, and dose. (NP-1999-No4).

The lexeme kalym underwent the process of changing the meaning in the 70th and was used in the meaning of «an illegal earnings» and now it stands for «a transportation of people».

- After that I am not taken for work anywhere. I don't know what to do and there is no place to kalym (to earn illegal earnings). And after all I have a driving license of chauffeur and tractor driver, even the driver of BMP. (Vremya-2000-№31).

The lexeme myrza was used in pre-revolutionary newspapers in the meaning of «an influential man», therefore usual semes of «a mister», «a person who occupied an aristocratic position» was often actualized in texts of newspapers. After revolution this word wasn't demanded and passed into the category of historicism. In the 90th we became witnesses of return of the word of myrza to the active use that found reflection in newspapers. Besides standing for «an official address to citizens» which was replaced by Soviet zholdas (companion), the lexeme myrza is often used with a definite stylistic purpose such as an expression of negative attitude (satirical):

- Myrzalar! As introduction of the law on transfer prices of oil isn't possible, I suggest considering the bill of meanness instead of it! (V.-2000-№7). Bonn appetite, doctor myrza! What a well to be a doctor, not simple, but sanitary, and not just anywhere, but in the market! (NP.-2000-№29).

It should be noted that a number of the archaisms and historicism which are actively used in recent years in the Russian-language newspapers have a process of narrowing of semantic structure by acquisition of an ironical tone (Zhumagulova V.I., 2001).

-It's said that the bill "'about tokal 'is received at the Mazhilis of the Parliament emergence of which is connected with deterioration of a demographic situation and mass emigration of officials (without wives) to Akmola (Caravan - 1998 - Feb.)

National-coloristic function is carried out by individual-author's comparisons and metaphors in language of modern Russian-language newspapers. They are formed by unexpected comparison of objects or phenomena, their extraordinary combination that allows to actualize valuable installations of the author (Zhuravlyova E.A., 1999). Compare:

- His immortal «Blizzard» expressed in a waltz rhythm was sounded, baton of the conductor Tolepbergen Abdrashev seemed to be taking out a huge handfuls 
of magic melodies from an orchestra and generously scattered them as shashu (sweets scattered on important events) through the hall (OA-2000 No. 49).

- This tendency in poetic metaphor was dressed by poet, the chief editor of magazine "Niva», the old resident of Akmola - the patriot Vladimir Gundarev, at one of creative meetings, who called Almaty as a careful mother, tearing her children off from heart for the purpose of blossom of the young bride Astana in the grass steppe, so that her rich saukele (a kind of head-dress) is visible at the other end of the world and the world could admire her talents. (KP-2000-№245).

Expressiveness of such comparisons and metaphors consists in their versatility, unexpectedness of the pulled together images.

Mode of transmission of the author's attitude to the described phenomena, actualization of the reader's attention on these or those tones of semantics of the word are served by the word-formation potential of language ( Krysin L. P., 1986).

- Then the general rule about the orderliness of pastime marking the end of an era of natural besbarmachestvo was declared (NP-2001-№3).

- Oh shaitan (devil) world! How congested in it (NP-1999 -No. 5).

From the recent past, first of all, comes to mind Peter Nefedov to whom the ex-public prosecutor Yurii Hitrin had tricky questions concerning privatization of miracles in Karaganda region where Petrovich was akim (head) (Vremya-2001-№4).

The draft of the new law was discussed by officials of Mazhilis during several days. (NP - 1999-№14).

The need for a wide nominative use of Kazakhisms in the language of the Russian-speaking periodicals was disappeared due to the high level of contemporary readership and a wide bilingualism of population of the country.

The original fusion of the Russian and Kazakh lexis is found in the modern Russian-language newspapers that allow publicists to reflect their author's vision of the world in terms of integration of both ethnic and linguistic systems.

\section{Conclusion}

The analysis of lexical-semantic groups of Kazakhisms from «Kyrgyz steppe newspaper», «Turgay newspaper», «Turkestan bulletin», «Semirechenskii regional bulletin» gave the chance to track active functioning of this lexis in social, economic and political life of the country in the II half of the XIXth century. While development of pre-revolutionary Kazakhisms the Russian lexicalsemantic system kept their semantic volume, however introduced changes in a connotation of meanings. Kazakhisms in the Russian-language newspapers («Novoe pokolenie» (New generation), «Caravan», «Vremya» (Time)) at the end of the XXth century possess a number of features: first, they are characterized by large number which is caused by the development of national consciousness and mass bilingualism of local population; secondly, the structure of Kazakhisms of the Russian-language newspapers of the recent years isn't static: the active completion by the new Kazakh words is accompanied by its no less active development. In this regard it is possible to speak about changes of semantics of this part of loans as the loan of the denoted realias taking place in this situation eliminates meaning of seme of «isolation of this realia from the world of native speakers"), thus changes its linguistic status; thirdly, a considerable reduction of time of stay of new Kazakhizm as undeveloped exoticism is noted in the Russian-language newspapers at the end of the XXth century. If such words as myrza (mister), hakim (akim- a head of a region), hadzh, hanym (miss, mistress), tokal (a younger wife), khan (imperator), saukele ( $a$ kind of headdress), sultan (a head of the country) and etc. were part of exoticisms( between 1917 - 1992) for quite a long time, now they are very quickly mastered and actively used by all native speakers of the Russian language.

Development of process of loans of Kazakhisms in connection with the development of the picture of the world, reflected on pages of newspapers, undoubtedly, is an indicator of change of psychology of its carriers.

\section{Abbreviated names of the used sources:}

KSG - «Kirgizskaya stepnaya gazeta» (Kyrgyz steppe newspaper) $(1888-1902)$.

TV - «Turkestanskie vedomosti» (Turkestan bulletin) $(1870-1890)$.

TG - «Turgayskaya gazeta» (Turgay newspaper) (1892-1903).

SON - «Semirechenskie oblastnye novosti» (Semirechenskii regional news) (1892-1903).

NP - «Novoe pokolenie» (New generation) (1997-2001).

OA-«Ogni Alatau» (Fires of Alatau) (1995-2000).

V - «Vremya» (Time) (1996 - 2001).

Car. - «Caravan» $(1996-2001)$.

KTS - Kazak tilinin sozdigi (Dictionary of the Kazakh language) - Almaty: Dayk - the Press, 1999.

KTTS - Kazak tilinin tusindirme sozdigi (Explanatory dictionary of the Kazakh language). Under the editorship of. A. Y. Yskakov-Alma-Ata: Gylym, 1979. 


\section{References}

Dmitriev N.K. (1982) Sistema tiyrkskih eazykov [System of Turkic languages]. Moscow. P. 507. (In Russian)

Fedorov A.V. (1983) Osnovy obshei teorii perevoda (lingvisticheskie problemy) [Fundamentals of General translation theory (linguistic problems)]. M., P. 103. (In Russian)

Krysin L. P. (1986) Zaimstvovaniya i zaimstvovannye slova [Borrowings and borrowed words]. M.:Nauka. 166p. (In Russian)

Lenger F. (1995) Kazakh yni. 1995. (In Kazakh).

Potebnya A. A. (1899) Iz zapisok po russkoi grammatike [From notes on Russian grammar]. Kharkiv. P. 27. (In Russian)

Sagdullaev D.S. (1975) Turkizmy v tvorcheskom kontekste S.P.Borodina (na materiale trilogii «Zvezdy nad Samarkandom» [In a creative context Turkisms S.P.Borodina (based on the trilogy of «Stars above Samarkand» ]. Almaty. 25 p. (In Kazakh)

Shitova O. G. (1986) Zapadnoevropeiskie zaimstvovaniyav russkoi razgovornoi rechi XVII veka (problema assimilahii) [Western European borrowings in Russian colloquial speech of the XVII century (the problem of assimilation)]: author's review. dis... cand. philol. sciences'. Tomsk. 26p. (In Russian)

Zueva R. S., Lee V. S. O perspektivach razvitiya naychnyx issledovanii v Kazachstane [About prospects of development of scientific research studies in Kazakhstan]. Vestnik KazNU. Philological series. 1996. Issue 3. P. 138. (In Kazakh)

Zhumagulova V.I. (2001) Satira I uymor v russkoyazychnoi presse Kazachstana: lingvisticheskii aspekt. [ Satire and humor in the Russian-language press in Kazakhstan: lingvuistic aspect]. Almaty. 300 p. (In Kazakh)

Zhuravleva E.A. (1999) Semantizaziya leksik v gazetnom tekste (na materiale kazahstanskoi pressy 1988-1998 gg. [Semantization vocabulary in newspaper text (based on the Kazakh press 1988-1998]. Almaty. 150 p. (In Kazakh) 